\title{
The Nigerian System of Education and the Need for Pragmatic Approach
}

\author{
M. A. Oyebamiji (Corresponding author) \\ Department of Adult and Non-Formal Education \\ Faculty of Education, University of Port Harcourt \\ P.M.B. 5323, Nigeria \\ E-mail: oyebamiji_adekola@yahoo.com \\ Chidi Omordu \\ Department of Educational Foundations \\ Faculty of Education, University of Port Harcourt \\ P.M.B. 5323, Nigeria
}

Received: July 4, 2011

Accepted: July 31, 2011

Published: October 1, 2011

doi:10.5430/wje.v1n2p98

URL: http://dx.doi.org/10.5430/wje.v1n2p98

\begin{abstract}
This paper attempted to reveal some inadequacies inherent in the Nigerian system of education and, how the pragmatic approach to education can help solve the problems of disfunctionality of the system. It does this by explaining the aims and features of the pragmatic philosophy of education. Furthermore, the paper gave answers to two basic questions: (i) what really went wrong in the Nigerian education system? And, (ii) How did it start? The paper used education according to the needs of the society, learning by doing, life-long education, Teaching to be related to learners' interests and experience and, the promotion of democracy in schools as canon for explaining the implications of pragmatism to the Nigerian system of education. Finally it is the opinion of the writers that the inculcation of the pragmatic approach to education will help makes the Nigerian system of education functional.
\end{abstract}

Keywords: Education system, Pragmatic approach, Nigerian system of education

\section{Introduction}

The disfunctionality of the Nigerian education system is the alarming stage. It has become a source of worry to many Nigerian educationist and the non-educationists alike. The contemporary Nigerian education system has failed to address the basic issues in the nation's life. For instance, unemployment, illiteracy, poverty, disease and superstition are on the increasing rate. Internet library sources on "Education in Nigeria" provide that in 2004 the Nigerian National Planning Commission described the country's education system as "dysfunctional". The reasons for this characterization included decaying institutions and ill-prepared graduates.

It is regrettable that even in the 21 st century, an era dominated by science and technology, the Nigerian system of education has little or nothing to contribute to the globalization process. The nation's education system can not best be said to be useful for its sake while at the same time being irrelevant to the individuals (recipients) and the nation at large. Of what use is a graduate who cannot perform creditably in the defense of his certificate? Knowledge gained from education should be used to solve the societal problems. If however, the recipients of a particular system of education cannot apply their knowledge to solve the societal problems, such graduates are simply 'educated illiterates'. Such is not the type of graduates a nation requires for its development. The majority of youths who are currently engaged in militancy, boko- haram, thugery, gansterism, cultism and other forms of anti-social behavior are usually people who received the dysfunctional type of education and who feel that they cannot make a living through any legitimate means.

By implication, every nation should have some development strategies. These strategies are reflected in the education system through its curriculum. So, the development of any nation is tied to the development, not of natural resources but first and foremost of human resources of the nation. Thus, education is inseparable from the needs and development of every nation; Nigeria cannot therefore, be an exception. But in contrast, the Nigerian system of education divorced from the needs of the Nigerian society. The courses offered in the nation's universities in most cases are irrelevant to societal needs, while the more relevant ones are not taken seriously. A situation where a country is faced with the problem of 
food security and yet, the number of students admitted to study agriculture and agro-allied courses are on yearly basis far less than the number required shows the lack of planning for manpower requirement in that economy. Another dimension of this problem reveals the lack of interest or inability of the graduates to use the knowledge acquired from school to solve the immediate problem of the society. They rather prefer executive offices to field work. The manpower requirement of the Nigerian society is in every respect divorced from the choice of University courses available and offered. Consequently, Nigeria still looks up to the developed countries for her manpower needs.

The graduates of this system are in most cases termed unemployable, skill-less employment seekers rather than having practical or entrepreneurial skills which should help the products of the school system to become self-employed. The result of this is that certificates obtained from the Nigerian institutions of learning are treated with levity outside the shores of the country.

This situation has defied the high hopes raised by the Ashby Commission Report (1960), the 1969 Curriculum Conference, the Universal Primary Education (1976), the National Policy on Education (1977, Revised 1981, 1989 and 2004), the Universal Basic Education (UBE) and the various interventions by the international organizations such as the United Nations Children Fund (UNICEF) and other blue prints largely been dashed.

As the crises in the nation's education deepen, it however, begs for solutions to the problems. This paper therefore, attempts to discuss the pragmatic approach to education and its implications to the inadequacies inherent in the Nigerian system of education.

\section{What Is Pragmatic Approach?}

Pragmatism is an outgrowth of British Empiricism. It is a school of thought which had its origin in North America. The originators of pragmatic school of thought are Charles S. Pierce (1839-1914), William James (1842 - 1910), and John Dewey $(1859-1952)$.

The word pragmatism is derived from the Greek word 'pragma' which means work. Hence, the most common interpretation of the term is what works, making it to be known in consequence as the philosophy or theory of workability (Enoh 1995:107). To the pragmatists what is true is what works- what enables one to overcome an immediate problem. In the words of Okoh (2003:36) "Pragmatism stresses action and doing and maintains that imaginative theorizing must be supported and controlled by the outcome of active experimentation".

Continuity, interaction, experience and meaning are key words to understand the pragmatic philosophy. To them, the entire universe is in a state of continuous change. Since the world is continuously a changing one, reality is not fixed. Therefore, man's conception of the nature of reality is determined by what he experience through interaction with the environment. In this process an individual experiences certain consequences as a result of his acting on some elements in the environment.

There is a positive relationship between knowing and action in the pragmatic philosophy; knowledge in this way is interactive. The pragmatists do not consider knowledge a quality waiting to be discovered. Rather, they seek knowledge as being created by man through interaction. We are able to create knowledge only when we master a given environment through interaction. In that process, knowledge is necessarily used to solve problems that arise from such environment. Furthermore, they favor the use of intelligence (reflective thinking) and scientific method, in which an individual learns by doing it for himself as the most reliable source of knowledge. Dewey in Enoh (1995:109) admits that "there is no such thing as genuine knowledge and fruitful understanding except as the offspring of doing". They hold that for an idea to be true, it must be shown to work and to provide satisfactory results. This is so because, the world is constantly changing and what works today may not work in future. There is therefore no absolute truth in pragmatism. Truth is always changing as the world itself changes.

Values in pragmatism are relative because all values are derived from human needs and desires. Man encounters one problem or the other. It is his urge to solve these problems that makes him react in certain ways. Those things which are likely to be beneficial in overcoming his problems will be of value to him. At the level of the society, value is attached to those things which have enabled it to survive over time. Survival to them depends on one's ability to use acquired intelligence to overcome problems of his existence. Abstract reasoning is not enough because for ideas to become useful they must be applied practically. Thus, they recommend the acquisition of skills.

The pragmatists believe in the democratic ideals because it is only in a democratic society where freedom, character, intelligence and other potentialities are developed. They also subscribe to life-long education to enhance the update of knowledge to be at equilibrium with the new realities in the changing world. As Dewey (1944:76), puts it, "education is the constant reconstruction or re-organization of experience". The ability to constantly apply experiences to meet the challenges of later problems is to the pragmatists, very necessary. And, to them, because the world is constantly 
changing, there are no already-made answers to problems hence, the need for life-long education so as to face the challenges that are bound to occur. This will ultimately lead to self-reliance.

In the pragmatic philosophy, the curriculum should be made to eliminate the gap that exists between what is learnt in school and the wider society. All genuine knowledge emanates from a problem or difficulty. This implies that an adequate curriculum must be an activity centered that will give opportunities to the learners to explore and solve problems themselves. Thus, pragmatism recommends learning by doing and, teaching to be related to pupil's interest and experience. Finally, the pragmatists see the role of the school as linking new experiences in school and those of the outer society.

\section{What Really Went Wrong?}

Education in Nigeria has very much been neglected and left to suffer a bad fate. A nation that neglects education does so at its risk. In Nigeria, we have allowed our education to cripple. The consequences are made manifest in different ways in our national life. In the first place, the contemporary Nigerian education does not equip its recipients to be self-reliance. It removes people from productive activities in industry and agriculture. It channels every educated man/woman to pen-pushing and white cola jobs or to the unproductive arena of politics, cut-throat capitalism, obtaining by tricks, fake contract award, and recently, the more lucrative kidnap for ransom. The reason behind this is that our education system has failed to make people to be self-reliant in their life endeavours.

The value attached to paper qualification in the Nigerian society has also caused more harm than good to the education sector. What matters is not what can be done but what certificate. This is to the extent that the acquisition of certificate has become a tool for social mobility whether relevant to the needs of the society or not. These distortions of education system include:

The emergence of education as a tool for social upliftment and mobility through the instrumentality of examinations, and the later emergence of malpractice including teacher immorality and cultism in the education institution. When considered as facts in themselves, these two phenomena represent the tremendous challenge towards repositioning education in Nigeria (Anikpo, 2006:6)

The implication of the above is that these certificates are acquired at all means and costs, including examination malpractice. It has given rise to a situation where certificates are acquired for the sake of securing employment at the expense of productivity. Thus, the country continues to suffer low outputs of goods and services, while looking up to foreign personnel to salvage her economy.

There is lack of confidence in the Nigerian education and its products. As a result, graduates of the Nigerian institutions of learning are in some cases, sent abroad to receive blessings from foreign institutions of learning before they are assigned duties. In the dominant oil sector, the key positions or technically sophisticated responsibilities are assigned to the foreigners on a very high income. This accounts for the reason why the country can hardly gain full control of its oil sector. One may be tempted to ask the relevance of the Nigerian education in the face of these difficulties. This crisis if not reversed, Nigeria may lose an entire generation or more of its skilled labour force.

\section{How Did It Start?}

Modern education came to Nigeria in the 1840s with the first mission school founded by the Methodists. This was followed by other missionary bodies like Anglican Church Mission, Roman Catholics and so on. Their primary objective was not to give education to the Africans but, to convert the children to Christianity. It was further hoped that the new Christians could be trained to assist the missionaries in their work as catechists, lay readers and teachers. As Kosemani \& Okorosaye - Orubite (1995:36) puts it "the curriculum of the early Christian schools in Nigeria included mostly the 4Rs- reading, writing, arithmetic and religion". Because the missionaries saw education as an aid to evangelism, there was an indiscriminate establishment of schools without recourse to science and technology. This distorted legacy of colonial education on African countries was not intended to prepare Nigerians for independence and nationhood/self-reliance.

However, the curriculum contents of the mission schools were not related to the local background. In fact, the schools were ill-equipped and ill-staffed.

...government as well as the British Trading Companies were critical of the products of these schools when in 1882 the ordinance for the promotion and Assistance was enacted. This ordinance (the first of its kind that affected Lagos) was aimed at the control of education by government in the Gold Coast colony of which Lagos was part. (Kosemani \& Okorosaye - Orubite 1995:37). 
Thus, the ordinance marked the beginning of dual joint participation (Government, private individuals and organization). But on the whole, the ordinance did not make much impact.

The colonial education in Nigeria focused strongly on examinations. In 1916, Frederick Lugard, first governor of the Unified Colony, set up a school inspectorate. Discipline, buildings and adequacy of teaching staff were to be inspected, but the most points given to a school's performance went to the numbers and rankings of its examination results. This stress on examinations is still used in the contemporary period to judge results and to obtain qualifications for jobs in government and the private sector in Nigeria (Wikipedia, 2008). This favor on examination initially, was used to judge intelligence, promotions and later qualification for job. As soon as it became obvious that success in examination is the entire certification one needed for success in the Nigerian society, many morally-bankrupt Nigerians resorted to the abuse of the system through all forms of examination malpractice. Thus, cheating to obtain certificate is now very common in the Nigerian education system; and certificates no longer express what an individual can do.

Before independence, the white man was to the Nigerian, the symbol of great success. The ingredients of this success comprised high education, large income, and luxurious houses full of domestic servants, leisure time and little or no manual work. After independence, this culture was not corrected. The educated Nigerian socialized and accepted that culture (Anikpo 2005:5). Consequently, this period marked the beginning of education divorced from productive activities in Nigeria. It marked the removal of manpower from the more practical productive sector of the economy and made every educated Nigerian man/woman not to get their hands dirty. Thus, the more educated the Nigerians become the more unproductive and the more hungry we become.

\section{Implications of Pragmatic Approach to the Nigerian Education}

Our choice of the pragmatic school of thought is obvious. It is an approach that is very much concerned with the application of knowledge in tackling the life challenges. Thus their aim of education is that knowledge acquired must have relevance to the need of the society. Some of the implications on the Nigerian system of education can be drawn from the following:

\subsection{Education according to the needs of the society}

Survival to the pragmatists depends on man's ability to use acquired intelligence to overcome the problems of his existence and that of his society. For ideas to become useful therefore, they must be applied practically. The pragmatists advocate individualism capable of over-coming the problems of the environment. The National Policy on Education (2004:9) recognizes this as it says that "efforts shall be made to relate education to overall community needs".

For the needs of the Nigerian society to be solved, the gaps that usually exist between what is learnt in school and its wider society must be eliminated. Nigeria should formulate educational policy that adapts the needs of the nation. Our educational policy should be made to help towards the solution of our present predicament as a nation. For instance, there should be Manpower Development Commission which should serve as a link between the manpower needs of the nation (according to the demand of employers of labour) and the quantity turned out by our Universities yearly. The commission can as well serve as guide to the candidates as well as information on the areas of knowledge that are high in demand.

\subsection{Learning by doing}

There is an inherent relationship between action and knowledge. The pragmatists believe that knowledge results when in our various interactions we experience the consequences of our actions and note the action-consequence relation of different experiences and uses this to solve subsequent problems. To create the necessary knowledge to solve problems therefore arises from interacting with such environment. By implication, it means that learning by doing will not only lead to skill acquisition, but also leads to the development of self-reliance. When people are self-reliant the problem of unemployment in the Nigerian society will be a thing of the past.

Learning by doing ultimately, reduces the quest for paper qualification. In pragmatism, action is combined with one's level of qualification. This encourages professionalization because for any one to prove his qualification, the necessary action must be followed in order to solve a problem. In Nigeria, there should be a symbiotic relationship between the formal school education and non-formal apprenticeship education in such a manner that the whole community becomes the resource centre for the education of the learner, and the wall of separation between the world of school and the world of work is broken down. This idea is being implemented in Tanzania, and reports have it that it is working well.

\subsection{Life-Long Education}

The entire universe the pragmatists say is in a state of continuous change and what works now may not work in a different situation. What the pragmatists propose is the type of education that continues till adulthood. Life-long 
education is a solution to the changing world; knowledge should be updated so as to take care of the problems arising from the changes in the universe. This type of education as Nzeneri (2010:13) puts it "is learning about anything at all that helps us understand the environment we live in, and the manner in which we can use and change this environment in order to improve ourselves".

Unfortunately, in Nigeria this aspect of education is not properly functional. We have not considered how the school drop-outs and the products of various literacy campaigns can rejoin the formal education system. There should be the possibility to give admission to products of adult education, apprenticeship, and other forms of non-formal education into appropriate section of formal school education when desired and, certificates obtained from the non-formal system should be recognized for employment purposes at appropriate levels.

To that effect, what the present moment demands is a new and long-term perspective on education. The fault of formal education has been that it is regarded as a complete entity by itself, and lacks continuity with non-formal and informal activities. An adequate philosophy of education will explore the ideological commitments of the nation, and embody these in a truly life-long and permanent education of which the formal education system, coming as it does in the most formative years of a man's life, is obviously the most important but by no means the only item. A realistic role of the school is that scheme will be found to be that of an enabling institution within a life-long educational continuum (Akimpelu, 2005:168).

\subsection{Teaching to be related to pupil's interest and experience}

Another aim of education in the Pragmatic school of thought is that teaching should be related to pupil's interest and experience. It favors a diverse curriculum in order to take care of differences and needs of the learners. The uniqueness of every individual has to be identified and developed. To expose every individual to the same curriculum is to ignore this important fact. In Nigeria, there should be a radical departure from the old one, where parents select courses for their children/ward without reference to potentiality of the learner. However, when these students are mis-directed and mis-guided into the preference of their parents, they probably end up being frustrated and consequently, they show lack of interest in the practice of their disciplines after graduation. This may further result into a situation where the graduate will abandon his profession and resort to office work.

Thus, some of the problems schools encounter comes from parents. Parents should keep off and allow the choice of what to study to be the function of interest, the learner's interest and his potency. The services of the guidance counselors are therefore needed if the students must make the right choice of career. It is in this direction that the government should make the guidance and counseling units of every school to be properly functional.

\subsection{Promotion of democracy}

Democracy and education have a symbiotic relationship in the pragmatic philosophy. While the business education should be necessarily democratic, the democratic ideals on the other hand, are strengthened by education. Thus, the pragmatists have been attracted by the idea of democracy because, as Enoh (1995:112) puts it, "they believe that it is only in a democratic community, where there is give and take and where free interaction between individuals and social groups exist, that human freedom, character, intelligence and other potentialities can develop".

It is therefore necessary that the Nigerian education be made to be democratic. Both the teachers and the learners are to see themselves as partners in the discovery and extension of knowledge. The teacher's authority must not be seen to derive from attempts to oblige the learner to accept whatever he says since he is an authority. To oblige the learner in such a way would militate attempts to develop in the learner, critical reasoning and critical evaluation of facts that knowledge claims are accepted not merely because somebody made some pronouncements but because adequate reasons have been furnished to support claims. The teacher is therefore required to work towards laying the foundations that will enable the child inculcate the spirit of role-playing and responsibility while in school. It is only when this is imbibed by the child that he sees himself as a responsible person even after the school life.

\section{Conclusion}

No nation can develop beyond the level of its education. To this end the educational curriculum of every nation especially Nigeria is to be reviewed from time to time so as to meet the challenges of the new realities. This will go a long way in making education relevant to the society in which it is operational. Furthermore, there is the need for Nigeria to de-emphasize paper qualification and focus on what the individuals can do. It is only by so doing that the philosophy of pragmatism will be made relevant to the system of education; and ultimately, eliminates the disfunctionality of the education system. 


\section{References}

Anikpo, M. (2005) Repositioning Education in Nigeria. A lead paper presented at the 4th Annual Conference of the National Association for Research Development held in the University of Port Harcourt.

Akinpelu, J. A (2005). Essays in Philosophy and Education. Oyo State: Stirling-Horden Publishers (Nig.)Ltd.

Dewey, J (1944). Democracy and Education. New York: The free press.

Enoh, A. O (1995). Introduction to philosophy of education. Jos: Midland Press (Nigeria) Ltd.

Kosemani, J. M \& Okorosaye - Orubite, A. K (1995). History of Nigerian Education: A Contemporary Analysis. Port Harcourt: University of Port Harcourt press.

Nzeneri, I.S. (2010). Adults in Battle: Any Hope of Victory? An Inaugural Lecture Series 71, Presented to University of Port Harcourt.

Federal Republic of Nigeria (2004). National Policy on Education. Lagos: NERDC Press.

Okoh, J.D. (2003). Philosophy of Education (The Basics). Port Harcourt: Pearl Publishers.

Wikipedia, (2008). Wikipedia the free encyclopedia, http://en.wikipedia.org/wiki/Education in Nigeria. 